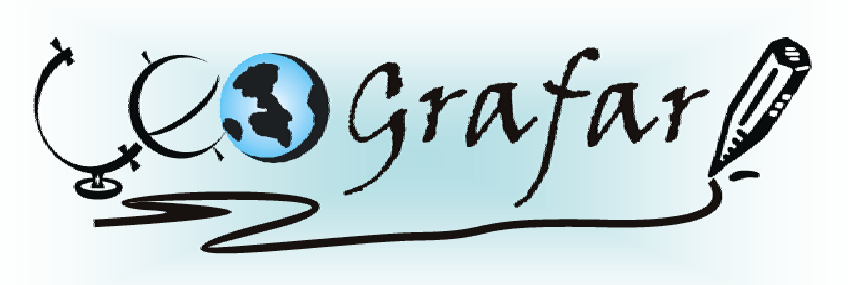

Revista Eletrônica do Programa de Pós-Graduação em Geografia - UFPR

\title{
CHÃO PARTIDO: CONCEITOS DE ESPAÇO NOS ROMANCES O QUINZE DE RAQUEL DE QUEIROZ E $A$ BAGACEIRA DE JOSÉ AMÉRICO DE ALMEIDA
}

\section{ALESSANDRO ANDRADE HAIDUKE ${ }^{1}$}

A literatura está repleta de formações espaciais, seja nas imagens da natureza e das paisagens utilizadas nas obras ou nos lugares de encenações de dramas sociais, psicológicos e políticos, todas essas formações que refletem uma determinada realidade da estória. Estudar o espaço geográfico dentro de um romance significa explorar vários níveis de espacializações, o primeiro composto pela trama em que se estrutura a obra literária e o segundo que se refere à organização espacial no qual o romance está embutido, o seu contexto histórico e social. Nessa pesquisa literária os textos a serem analisados são: "O Quinze" de Raquel de Queiroz e "A Bagaceira" de José Américo de Almeida, ambos romances inseridos em uma tradição literária denominada regionalismo. O regionalismo surge na década de 30 e utiliza como temática a descrição da realidade social da periferia brasileira. No Nordeste, o regionalismo tem como tema principal a luta do homem frente ao semi-árido da paisagem. Dentro da obra literária observam-se técnicas específicas com as quais o autor cria, investiga e reproduz espacialidades no desenvolvimento de sua estória. Além de uma discussão da paisagem natural e urbana, criam-se descrições de conflitos psicológicos e conflitos sociais entre os personagens (encenações). Estas espacializaões eram utilizadas para uma crítica política com relação aos problemas associados à seca na região Nordeste. Fundamentados em referenciais teóricos como a geografia humanista e a teoria literária de Bakhtin, pretendemos desenvolver uma análise da evolução na construção espacial e territorial dentro dos romances e na sua época. $\mathrm{Na}$ forma literária tentamos, conforme as idéias do cronótopo de Mikhail BAKHTIN, compreender a configuração específica de tempo e espaço na obra artística literária. Além disso, propõe-se uma análise da configuração dos atores nos romances com os seus respectivos espaços estéticos e sociais e uma contextualização das obras nas discussões políticas-territoriais da época.

Palavras chave: espaço geográfico, literatura, Nordeste.

${ }^{1}$ Mestrando em Geografia - UFPR - email: alessandrohaiduke@hotmail.com Orientador: WOLF DIETRICH SAHR 